\title{
O Salmo 101 e sua relação com a monarquia e com o culto
}

\author{
Orientadora: Maria de Lourdes Corrêa Lima \\ Mestrando: Juscelino Fernandes Carneiro \\ Área de Concentração: Teologia Bíblica
}

Linha de Pesquisa: Análise e Interpretação de Textos do Antigo e Novo Testamento

O salmo 101 é analisado em sua relação com a monarquia e com o culto, enfatizando-se os vv. 2 e 6 , onde sobretudo se notam indícios que permitem explorar essa relação. No poema o rei deseja cantar o amor e o direito de YHWH, - dons divinos outorgados a Israel e Davi - respondendo não apenas através do culto, mas também através de um estilo de vida em fidelidade à Lei de YHWH. Este projeto de vida, caminho sem mancha, se torna critério na escolha dos seus colaboradores e deve pautar a vida de todos os habitantes da cidade de Deus. Através da pergunta "quando virás a mim?", no v. 2, o rei reclama a vinda de YHWH até ele, para que ele seja capaz de realizar seus propósitos de fidelidade. No v. 6 o verbo תרש, "servir", que é usado para designar o serviço cúltico a Deus, e aqui designa serviço ao rei, parece indicar uma proximidade entre o ambiente monárquico e o ambiente cúltico. Essa proximidade se depreende também do discurso real, que revela que o critério norteador da vida do rei e dos que são admitidos à corte é semelhante ao que, segundo as liturgias de ingresso, deve orientar a vida dos que são admitidos ao templo: a fidelidade à Lei. Portanto, enquanto no v. 2 o rei reconhece sua dependência de YHWH, no v. 6, parece estabelecer sua corte, de certa forma, em dependência ao templo.

Palavras-chave: Teologia Bíblica; Salmos; Monarquia no Antigo Testamento. 